\title{
Physicochemical characterization and behavior of biocompounds of caja-manga fruit (Spondias mombin L.)
}

\author{
Thays Lorrayne Lavrinha e SILVA ${ }^{1}$, Edson Pablo da SILVA ${ }^{1}$, Eduardo Ramirez ASQUIERI ${ }^{1}$, \\ Ellen Caroline Silverio VIEIRA ${ }^{1}$, Jéssyca Santos SILVA ${ }^{1}$, Flávio Alves da SILVA ${ }^{1}$, Clarissa DAMIANI ${ }^{1 *}$
}

\begin{abstract}
The aim of this study was to evaluate the physicochemical changes and the antioxidant potential of caja-manga (Spondias mombin L.) fruit during its physiological development. The cycle comprised a period of 260 days after anthesis (DAA), set when the fruits were yellow-orange colored and easily detached from the pads. The results showed that the fruits had simple sigmoid type of growth pattern, with significant increase in mass, and longitudinal and transverse diameters up to 220 DAA. A decrease in total pectins and an increase in soluble pectins, lower acidity and chlorophyll levels, and masking of carotenoids exposure was observed, leading to color changes and softening in fruit. Significant changes were observed from 200 to 220 DAA, which may be the period that fruit has reached its maturity, emphasizing phenolic, vitamin $\mathrm{C}$ and antioxidant activity.
\end{abstract}

Keywords: Spondias Mombin; bioactive compounds; fruit physiology; cerrado fruits.

Practical Application: The study of physiological development of fruits, is necessary because this studies give support for harvest in the period physiological optimum with maximum value nutrients and enabling the development of new food products using a raw material, with high value nutritional, minimizing lost resulting of biochemical reactions. Thus, the knowledge of news raw material rich in bioactive compounds and high nutritional content is essential in the obtainment of new food products, contributing in the preservation and propagation of Brazilian fruits.

\section{Introduction}

Caja tree is native to tropical America and belongs to the Anacardiaceae family, Spondias genus, and produces a fruit known as caja-manga (Spondias mombin L), with your pulp, peel, and seeds, very appreciated in Brazil, and utilized of natural form or in of beverages, candies, ice creams, and jellies (Mattietto et al., 2010; Carvalho et al., 2008; Franquin et al., 2005; Miller \& Schaal, 2005).

Fruit growth is characterized by rapid division and cell elongation, with an irreversible increase in weight, diameter, and length, which are influenced by genetic and environmental factors such as temperature, solar radiation, and precipitation (Berilli et al., 2007). The ripening stage leads to physiological maturity, defined as the stage where the fruit will continue developing even detached (Watada et al., 1984), when considering the climacteric fruits.

At the end of maturation, ripening starts with changes in nutritional and sensory characteristics, such as changes in color, texture, flavor, and aroma, transforming them into acceptable and commercially attractive products (Chitarra \& Chitarra, 2005). At the end of ripening, there is a reduction of the synthesis and a predominance of degradation processes, that characterize the senescence stage. The main physiological changes that occur at this stage are loss of sensory and nutritional characteristics
(Oms-Oliu et al., 2011). Fruit development happens according to the physiological processes from plant forming until death, including growth, maturation, physiological maturity, ripeness, and senescence (Watada et al., 1984).

Bioactive compounds are essential compounds or not which are naturally present in foods and which have several beneficial properties for health, mainly related to their antioxidant power. They are divided into different groups with distinct characteristics, being synthesized along the development and the tannins (Albuquerque et al., 2016). Although cajá-manga fruits shows good acceptance in the market due to its attractive sensorial characteristics, studies that involve its physiological characterization are scarce, being necessary this characterization so that one has previous knowledge for the extension of the useful life of the fruit. For that, the knowledge of the physiological development of the fruit, as well as the ideal harvest is fundamental. According to Tiburski et al. (2011), caja-manga pulp contains significant amounts of antioxidant compounds, such as phenolics, and high carotenoids, tannins, and vitamin C levels.

This study aimed to evaluate the physicochemical changes of caja-manga (Spondias mombin L.) fruit over the development stages from anthesis to maturity, emphasizing the changes in antioxidant activity during its physiological development. 


\section{Materials and methods}

\subsection{Temperature and relative humidity}

The temperature and relative humidity were measured with the aid of digital thermo-hygrometer with external sensor (Incoterm) during harvesting. From September (2014) to June (2015), the air temperature ranged from 22.90 to $32.20{ }^{\circ} \mathrm{C}$ with relative humidity between 38 to $85 \%$ at the time of the fruit harvest.

\subsection{Plant material and evaluation of fruit development}

Fruits were collected from September 2014 to June 2015, at Jabuticabal Farm in New Fatima, Hidrolandia district Goias, Brazil (1655’32.35 latitude 'S, 49²1’39.76 “O longitude). The experiment was conducted in a completely randomized design (CRD) composed of twelve collection periods $(40,60,80,100,120,140,160,180,200,220,240$, and 260 DAA).

During flowering, $10 \%$ of specimens of L. Spondias mombin were selected at random, and flowers were identified with woolen yarns of various colors at the time of anthesis, in different positions of the plant. The first harvest took place after the formation of fruits 40 days after anthesis (DAA), and the other at intervals twenty days up to $260 \mathrm{DAA}$, in the maturation stage, characterized by yellowing of the peel, totaling 12 collection points.

Fruits were harvested at random, in the morning, divided into four equal batches, representing the replicates.

\subsection{Physicochemical characterization}

Forty fruits of each development stage were characterized immediately after harvesting for fresh weight, longitudinal diameter (LD), and transverse diameter (TD) using semi-analytical balance (Mettler PC 2000) and digital caliper (Leetools $150 \mathrm{~mm}$ ), and the results were expressed in $\mathrm{g}$ and $\mathrm{cm}$, respectively. Color $\left(\mathrm{L}^{*}, \mathrm{a}^{*}, \mathrm{~b}^{*}\right.$, chroma, and ${ }^{\circ} \mathrm{h}$ ) was determined at different points of the peel (epicarp), using a HunterLab Colorimeter (ColorQuest II Sphere). Firmness was determined in Texture Analyzer model TA -XT Plus equipped with $2 \mathrm{~mm}$ needle-like probe, with six measurements at different points of each fruit, and the results were expressed in Newtons (N).

Total soluble solids (TSS), $\mathrm{pH}$, and titratable acidity (TA) were determined for each development stage, in six repetitions. Soluble solids (SS) of the pulp were measured with digital refractometer (ATAGO PR-100), with automatic temperature compensation to $25{ }^{\circ} \mathrm{C}$. The results were expressed as ${ }^{\circ}$ Brix. The titratable acidity (TA) was determined by titration with $0.1 \mathrm{M} \mathrm{NaOH}$ solution using phenolphthalein as indicator. The results were expressed as $\mathrm{g} 100 \mathrm{~g}^{-1}$ pulp in natura, considering citric acid as the predominant acid. The $\mathrm{pH}$ of the pulp was measured using a portable $\mathrm{pH}$ meter TECNAL (Tec 3MP), according to the methodology of AOAC (Association of Official Analytical Chemists, 2012).

The fruits were frozen in liquid nitrogen, and stored in a freezer until time of analysis.

\subsection{Total and soluble pectins}

The total and soluble pectins were extracted according to the technique described by McCready \& McComb (1952), and determined in a spectrophotometer at $520 \mathrm{~nm}$, according to Bitter \& Muir (1962). The results were expressed as g galacturonic acid $100 \mathrm{~g}^{-1}$ pulp.

\subsection{Chlorophyll and carotenoids}

For determination of chlorophyll in the peel, $1 \mathrm{~g}$ sample was triturated in $10 \mathrm{~mL}$ of $80 \%$ acetone with the aid of a mortar. The extract was transferred to a $25 \mathrm{~mL}$ volumetric flask, and volume was completed with $80 \%$ acetone. After 12 hours of rest in the dark, the extract was filtered, and readings were performed in spectrophotometer (BiospectroSP-220) at $652 \mathrm{~nm}$. The results were calculated using the equation adopted by Engel \& Poggiani (1991) and expressed as $100 \mathrm{mg}^{-1} \mathrm{~g}$ peel.

Total carotenoids in the peel were determined in spectrophotometer (BiospectroSP-220), with readings at $450 \mathrm{~nm}$ according to Higby (1962). The results were expressed as mg of total carotenoids $100 \mathrm{~g}^{-1}$ peel.

Obtaining the extracts for determination of antioxidant activity and phenolic compounds

The ether, alcoholic, and aqueous extractions were performed simultaneously. For that, $2.5 \mathrm{~g}$ sample was placed in a beaker covered with aluminum foil to avoid contact with the light. Then, $50 \mathrm{~mL}$ ethyl ether was added with stirring at room temperature for 1 hour (Quimis, Q261-22). The extract was filtered through filter paper, and the volume was completed to $50 \mathrm{~mL}$ with ethyl ether. The remaining residue was subjected to drying at $45^{\circ} \mathrm{C}$ for 1 hour, for using in the alcoholic extraction. The filtrate (ether extract) was stored in amber bottle. Absolute ethanol was added to the residue in the ratio of 1:20 (w/ v), followed by stirring and filtration under the same conditions of the ether extraction. The volume was completed with absolute ethanol, and the extract was stored in amber bottle. For the aqueous extraction, distilled water was added in the ratio of 1:20 (w/v), dried at $45^{\circ} \mathrm{C}$ for 1 hour, followed by stirring and filtration as previously reported for the ether and alcoholic extractions. The volume was completed with distilled water, and the extract was stored in amber bottle. The ether, alcoholic, and aqueous extracts were stored in a freezer at $-18{ }^{\circ} \mathrm{C}$, for determination of antioxidant activity (DPPH, ABTS, and FRAP) and total phenolics content.

\subsection{Antioxidant activity by DPPH}

The DPPH (2,2-diphenyl-1-picrylhydrazyl) assay was performed according to Borguini (2006). The degree of discoloration of the DPPH radical by the action of antioxidants was measured in the ether, ethanolic, and aqueous extracts $\left(0.2 \mathrm{mg} \cdot \mathrm{mL}^{-1}\right)$ in spectrophotometer (BiospectroSP-220) at $517 \mathrm{~nm}$ after 20 minutes of reaction. The results were expressed as IC50. 


\subsection{Antioxidant activity by ABTS}

The total antioxidant activity was determined by the method of capture of free radical ABTS (2,2' -azinobis (3-ethylbenzthiazoline6-sulfonic acid), as reported by Rufino et al. (2007). The absorbance was measured in the ether, ethanolic, and aqueous extracts in spectrophotometer (BiospectroSP-220) at $734 \mathrm{~nm}$., using a standard curve in the range of 0 to $1000 \mathrm{uM}$ Trolox, and the results were expressed as $\mathrm{mM}$ Trolox equivalents (TE) $\mathrm{g}^{-1}$ pulp.

\subsection{Ferric reducing antioxidant power - FRAP}

The FRAP method was performed according to Rufino et al. (2006). The absorbance was measured in the ether, ethanolic, and aqueous extracts in spectrophotometer (BiospectroSP-220) at $593 \mathrm{~nm}$, using a standard curve in the range of 50 to $2000 \mathrm{mM}$ of ferrous sulfate, and the results were expressed as $\mathrm{mM}$ ferrous sulfate $\mathrm{g}^{-1}$ pulp.

\subsection{Total phenolic compounds}

The total phenolics were determined in the ether, ethanolic, and aqueous extracts in spectrophotometer (BiospectroSP-220) at $750 \mathrm{~nm}$, according to Waterhouse (2002), using a gallic acid standard curve in the range of 0 to $15 \mathrm{mg}$ of gallic acid $\mathrm{L}^{-1}$, and the results were expressed as $\mathrm{mg}$ of gallic acid equivalents (GAE) $\mathrm{g}^{-1}$ pulp.

\subsection{Condensate tannins}

The condensate tannins were determined in the caja-manga pulp, according to the method of Price et al. (1978), with adaptations by Barcia et al. (2012), in a spectrophotometer (Biospectro SP-220) at $500 \mathrm{~nm}$. A standard curve of catechin in the range of 600 to $1200 \mathrm{mg} \mathrm{L}^{-1}$ was used, and the results were expressed as milligrams of catechin equivalent $\mathrm{g}^{-1} \mathrm{pulp}$.

\subsection{Hydrolysable tannins}

The hydrolysable tannins were determined in the caja-manga pulp, according to the method of Brune et al. (1991), with adaptations by Barcia et al. (2012), in a spectrophotometer
(Biospectro SP-220) at $680 \mathrm{~nm}$. A standard curve of gallic acid in the range of 20 to $120 \mathrm{mg} \mathrm{L}^{-1}$ was used, and the results were expressed as mg of gallic acid equivalent $\mathrm{g}^{-1}$ pulp.

\subsection{Ascorbic acid}

The ascorbic acid content was determined according to Strohecker \& Henning (1967), in a spectrophotometer (BiospectroSP-220) at $520 \mathrm{~nm}$. The results were expressed as mg ascorbic acid $100 \mathrm{~g} \mathrm{pulp}^{-1}$.

\section{Statistical analysis}

Analyses were performed in triplicate. The results were submitted to analysis of variance (ANOVA), Duncan test $(\mathrm{p} \leq 0.05)$ and regression analysis, using Statistica software (version 8.0, StatSoft Inc., Tulsa, Oklahoma), and the results were expressed as mean \pm standard error (SE).

\section{Results and discussion}

\subsection{Changes in mass, diameter, firmness, and soluble and total pectins during fruit ripening}

The flowering of the caja-manga started in early September 2014, and finished in the first half of October. The initial fruiting occurred in the first half of October of the same year, peaking in November. Flowering until harvest comprised a period of 260 days, considering from anthesis to harvest, set when the fruits were yellow-orange colored and easily detached from the pads.

The mass, transverse diameter, and longitudinal diameter of caja-manga (Spondia mombin L.) increased significantly during fruit growth (Table 1).

The maximum transverse diameter $(4.86 \mathrm{~cm})$ was reached at 200 DAA, while the maximum longitudinal diameter $(6.68 \mathrm{~cm})$ and great mass (93.12 g) were observed at $220 \mathrm{DAA}$, showing that fruits have reached maturity from 200 to 220 DAA, with greenish color.

According to the growth parameters of caja-manga of this study, the fruits exhibited a simple sigmoid type of growth

Table 1. Mass, longitudinal diameter, transverse diameter, firmness, total pectin, and soluble pectin of caja-manga (Spondias mombin L.) along the physiological development.

\begin{tabular}{|c|c|c|c|c|c|c|}
\hline $\begin{array}{l}\text { DDAA Anthesis } \\
\text { after day }\end{array}$ & $\begin{array}{l}\text { Mass } \\
(\mathrm{g})\end{array}$ & $\begin{array}{l}\text { Longitudinal } \\
\text { diameter } \\
(\mathrm{cm}) \\
\end{array}$ & $\begin{array}{l}\text { Transverse } \\
\text { diameter } \\
(\mathrm{cm})\end{array}$ & $\begin{array}{l}\text { Firmness } \\
(\mathrm{N})\end{array}$ & $\begin{array}{c}\text { Total pectin } \\
\text { (g galacturonic acid } \\
100 \mathrm{~g}^{-1} \text { ) }\end{array}$ & $\begin{array}{c}\text { Soluble pectin } \\
\text { (g galacturonic acid } \\
100 \mathrm{~g}^{-1} \text { ) }\end{array}$ \\
\hline 40 & $0.5 \pm 0.03 \mathrm{a}$ & $1 \pm 0.02 \mathrm{a}$ & $0.9 \pm 0.02 \mathrm{a}$ & $13.1 \pm 0.24 \mathrm{a}$ & $1.2 \pm 0.03 \mathrm{ef}$ & $0.08 \pm 0.03 \mathrm{~d}$ \\
\hline 60 & $3 \pm 0.1 \mathrm{a}$ & $2.4 \pm 0.04 b$ & $1.5 \pm 0.02 \mathrm{~b}$ & $14.4 \pm 0.16 b$ & $1.1 \pm 0.03 \mathrm{bc}$ & $0.05 \pm 0.03 c$ \\
\hline 80 & $10 \pm 0.3 b$ & $3.6 \pm 0.05 c$ & $2.3 \pm 0.03 c$ & $15.6 \pm 0.30 \mathrm{~b}$ & $1.2 \pm 0.03 \mathrm{ef}$ & $0.03 \pm 0.03 b$ \\
\hline 100 & $18 \pm 0.5 c$ & $4.5 \pm 0.05 \mathrm{~d}$ & $2.9 \pm 0.03 \mathrm{~d}$ & $20.6 \pm 0.34 c$ & $1.1 \pm 0.01 \mathrm{~cd}$ & $0.03 \pm 0.01 \mathrm{a}$ \\
\hline 120 & $39 \pm 1.2 \mathrm{~d}$ & $5.2 \pm 0.06 \mathrm{e}$ & $3.7 \pm 0.05 \mathrm{e}$ & $27 \pm 0.40 \mathrm{f}$ & $0.1 \pm 0.02 \mathrm{~b}$ & $0.08 \pm 0.02 \mathrm{~d}$ \\
\hline 140 & $50 \pm 1.1 \mathrm{e}$ & $5.5 \pm 0.06 \mathrm{f}$ & $4.1 \pm 0.03 \mathrm{f}$ & $26 \pm 0.62$ ef & $0.8 \pm 0.02 \mathrm{a}$ & $0.14 \pm 0.02 \mathrm{f}$ \\
\hline 160 & $64 \pm 1.1 \mathrm{f}$ & $6 \pm 0.1 \mathrm{~g}$ & $4.4 \pm 0.03 \mathrm{~g}$ & $26.4 \pm 0.55 \mathrm{ef}$ & $1.3 \pm 0.06 \mathrm{e}$ & $0.08 \pm 0.06 \mathrm{~d}$ \\
\hline 180 & $79 \pm 1.4 \mathrm{~g}$ & $6 \pm 0.2 \mathrm{gh}$ & $4.7 \pm 0.03 \mathrm{~h}$ & $25.5 \pm 0.46 \mathrm{e}$ & $1 \pm 0.03 b$ & $0.15 \pm 0.03 \mathrm{fg}$ \\
\hline 200 & $82 \pm 1.1 \mathrm{~g}$ & $6.3 \pm 0.06 \mathrm{~h}$ & $4.9 \pm 0.03 \mathrm{i}$ & $25.6 \pm 0.61 \mathrm{ef}$ & $1 \pm 0.04 b c$ & $0.11 \pm 0.04 \mathrm{e}$ \\
\hline 220 & $93 \pm 2.5 \mathrm{~h}$ & $6.7 \pm 0.1 \mathrm{i}$ & $4.9 \pm 0.05 \mathrm{i}$ & $23.1 \pm 0.58 \mathrm{~d}$ & $1 \pm 0.03 b$ & $0.17 \pm 0.03 \mathrm{~g}$ \\
\hline 240 & $96 \pm 2.2 \mathrm{~h}$ & $6.9 \pm 0.1 \mathrm{i}$ & $4.9 \pm 0.05 \mathrm{i}$ & $25.1 \pm 0.41 \mathrm{e}$ & $1.1 \pm 0.02 \mathrm{de}$ & $0.2 \pm 0.02 \mathrm{~h}$ \\
\hline 260 & $97 \pm 5.8 \mathrm{~h}$ & $6.8 \pm 0.1 \mathrm{i}$ & $4.9 \pm 0.10 \mathrm{i}$ & $15.6 \pm 0.58 \mathrm{~b}$ & $1.1 \pm 0.03 \mathrm{bc}$ & $0.3 \pm 0.03 \mathrm{i}$ \\
\hline
\end{tabular}

Data represent mean \pm standard error. Different letters in the same column indicate significant differences by Duncan test ( $\mathrm{p} \leq 0.05)$. Values on a wet basis. 
pattern, evidenced by a significant accumulation of mass, and higher longitudinal and transverse diameters (Table 1). The growth rate increased from 40 to $100 \mathrm{DAA}$, with a higher rate from 100 to $120 \mathrm{DAA}\left(0.97 \mathrm{G}-20\right.$ days $^{-1}, 0.03 \mathrm{~cm} 20$ days $^{-1}$,

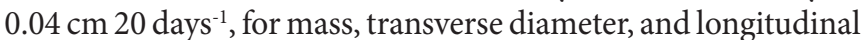
diameter, respectively) remaining stable from 120 to $200 \mathrm{DAA}$, followed by reduction from 200 to 260 DAA.

Firmness was affected with fruit development, with an increase to $120 \mathrm{DAA}(27.02 \mathrm{~N})$, followed by period of stability up to $200 \mathrm{DAA}(25.64 \mathrm{~N})$, followed by a reduction at $220 \mathrm{DAA}$ $(23.15 \mathrm{~N})$, reaching $15.57 \mathrm{~N}$ at $260 \mathrm{DAA}$ (Table 1). These results demonstrated that fruit firmness tended to decrease after 200 DAA, after reaching maturity. Similar results were found by Wongmetha et al. (2015), in mango cv. Jinhwang (M. Indica L.) coming from Pintung (Taiwan), during the fruit development, with higher firmness from 50 DAA (5.35 kgf) to 110 DAA ( $25.9 \mathrm{kgf})$, followed by a decrease up to full maturity at 140 DAA (8.05 kgf).

According to Prasanna et al. (2007), lower firmness may be to the depolymerization of pectin cell wall, resulting in pectin solubilization, degradation of polysaccharides, and enzymatic reactions catalyzed by glycanases, glycosidases, and esterases.

During the development stage, there was a reduction in total pectin levels (Table 1), whereas the soluble pectins (Table 1) levels increased significantly from 40 DAA to $260 \mathrm{DAA}$ (1.23 to 1.06 , and 0.08 to $0.27 \mathrm{~g}$ galacturonic acid $100 \mathrm{~g}^{-1}$, respectively). As reported by Lima \& Durigan (2002), the increase in soluble pectin indicates softening of the fruit due to degradation of pectic compounds to soluble galacturonic acid by the action of enzymes, such as pectin methyl esterase and poligalacturanase. Silva et al. (2016) studied the development stage of Murici (Byrsonima crassifolia Kunth) fruit coming from Roraima (Brazil), and obtained similar behavior in relation to total and soluble pectins, detecting the activity of the enzymes methyl esterase and poligalacturanase on these compounds.

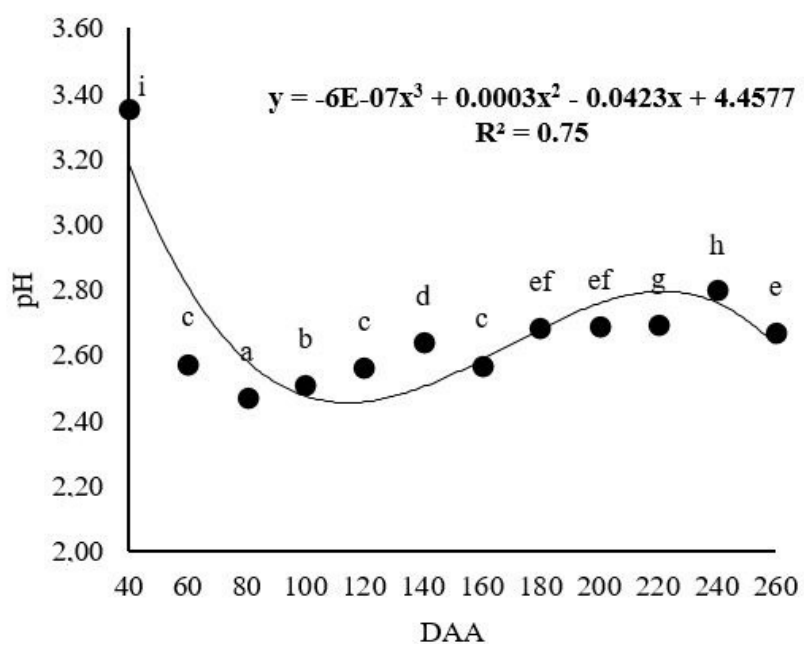

\subsection{Changes in $\mathrm{pH}$ and titratable acidity during fruit ripening}

Changes in $\mathrm{pH}$ and titratable acidity were observed during the development stage of caja-manga (Figure 1A and 1B).

A reduction of $\mathrm{pH}$ (Figure 1A) was observed from $40 \mathrm{DAA}$ $(3.36 \pm 0.02)$ to $80 \mathrm{DAA}(2.47 \pm 0.01)$, with a significant increase at $260 \mathrm{DAA}(2.67 \pm 0.00)$, which was lower than the $\mathrm{pH}$ value of $2.83 \pm 0.01$ reported by Tiburski et al. (2011) in caja-manga (Spondias mombin L.) pulp coming from Aracaju (Brazil).

A decrease in titratable acidity (Figure 1B) was observed from 40 to $260 \mathrm{DAA}$, with values of $3.14 \pm 0.00 \mathrm{~g}^{100 \mathrm{~g}^{-1} \text { to }}$

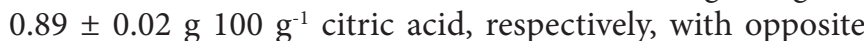
behavior observed for $\mathrm{pH}$ after $80 \mathrm{DAA}$, which increased from $2.47 \pm 0.01$ to $2.67 \pm 0.00$ from 80 to $260 \mathrm{DAA}$, respectively.

The decrease in acidity may be due to the participation of organic acids in the biochemical respiration, which is essential for synthesis of new organic compounds such as sugars and phenolic compounds during the fruit development stage (Matarazzo et al., 2013).

\subsection{Changes in color, carotenoids, and chlorophyll of fruit peel during physiological development}

Changes in color of caja-manga peel were observed, evidenced by the coordinates $\mathrm{L}^{\star}, \mathrm{a}^{\star}, \mathrm{b}$, hue, and Chroma (Figure 2 ).

No significant decrease in $L^{*}$ value (Figure $2 \mathrm{~A}$ ) was observed with the course of fruit development from 40 to 140 DAA ( $58.52 \pm 0.60$ to $52.14 \pm 0.34$, respectively), followed by variations, and remaining stable up to 260 DAA (52.09 \pm 0.80$)$, which was more evident in the early development stage, followed by darkening at the end of the evaluation.

A significant increase in $\mathrm{a}^{*}$ (Figure $2 \mathrm{~B}$ ) and $\mathrm{b}^{*}$ values (Figure 2C) was observed. The fruits started to develop at $40 \mathrm{DAA}$, in the range of green and blue $\left(\mathrm{a}^{*}=-4.64 \pm 0.67\right.$,

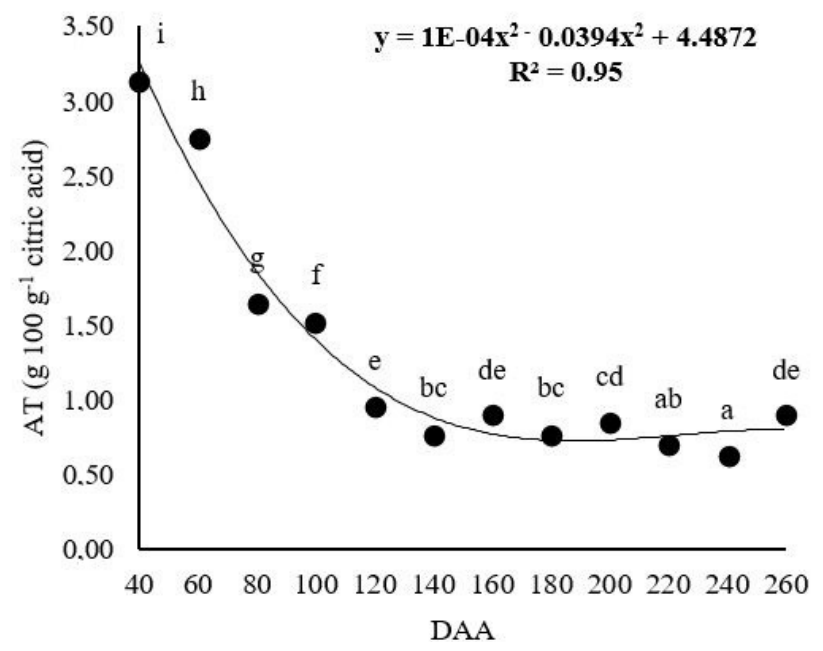

Figure 1. pH and titratable acidity of caja-manga (Spondias mombin L.) pulp along the physiological development. Different letters in the same graph indicate significant differences by Duncan test $(\mathrm{p} \leq 0.05)$. DAA $=$ Days after anthesis; AT = titratable acidity. Values on wet basis. 

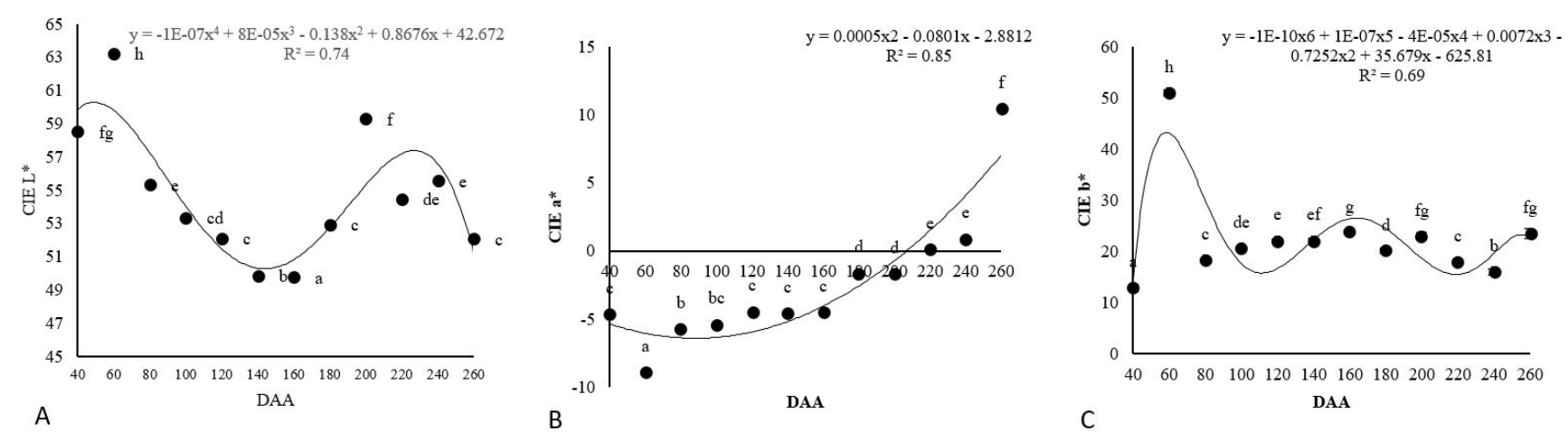

A
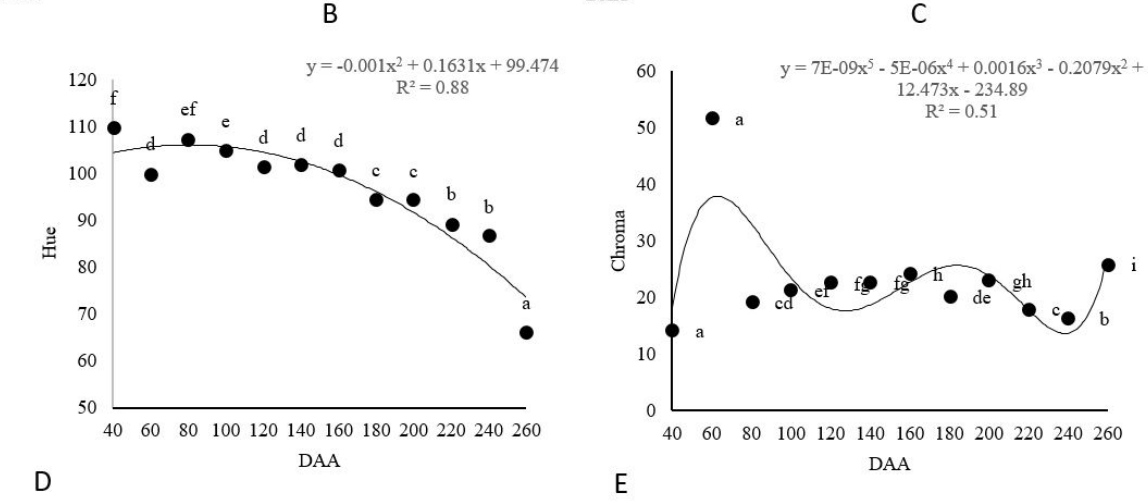

Figure 2. Color measurements of caja-manga (Spondias mombin L.) fruit along the physiological development. Different letters in the same graph indicate significant differences by Duncan test $(\mathrm{p} \leq 0.05)$. DAA $=$ Days after anthesis.

and $\left.b^{*}=12.86 \pm 0.69\right)$, with loss of intensity of green color in the course of the development stage, becoming red and yellow $\left(\mathrm{a}^{\star}=10.42 \pm 0.68^{*}\right.$ and $\left.\mathrm{b}^{\star}=23.52 \pm 1.00\right)$ at $260 \mathrm{DAA}$. Hue angle (Figure 2D) decreased during the development stage, ranging from $109.76 \pm 02.10$ to $66.08 \pm 1.32$, from 40 to $260 \mathrm{DAA}$, respectively, indicating color tending more towards red at the end of the physiological development.

This behavior is due to the reduction of chlorophyll levels (Table 2), which ranged from 38.06 to $2.85 \mathrm{mg} 100 \mathrm{~g} \mathrm{~g}^{-1}$, from 40 up to 260 DAA. According to Taiz \& Zeiger (2004), reduced green coloring occurs mainly due to losses in structural chlorophyll caused by several factors including changes in $\mathrm{pH}$, influenced by the accumulation of organic acids in the vacuoles, oxidative and enzymatic reactions, leading to the synthesis or unmasking of carotenoids in the vacuoles.

Over the development stage of caja-manga, there was a reduction in carotenoids levels (Table 2), ranging from 1.85 to $0.85 \mathrm{mg} 100 \mathrm{~g} \mathrm{~g}^{-1}$ peel, from 40 to $260 \mathrm{DAA}$, which may have masked the pigment.

Chroma values (Figure 2E) changed throughout the fruit development, with an increase from $14.23 \pm 0.72$ (40 DAA) to $25.86 \pm 1.05$ (260 DAA), reflecting the loss of lightness and slight variations in the tone of caja-manga peel.

\subsection{Total phenolics content, hydrolysable tannins, condensate tannins, vitamin $C$, and antioxidant capacity}

The total phenolics content (Table 3) was influenced by the development stage of caja-manga. There was a significant decrease in total phenolics in the alcoholic extract, with
Table 2. Chlorophyll and carotenoids levels in caja-manga (Spondias mombin L.) peel along the physiological development.

\begin{tabular}{|c|c|c|}
\hline $\begin{array}{l}\text { DAA Anthesis } \\
\text { after day }\end{array}$ & $\begin{array}{c}\text { Chlorophyll } \\
\left.\text { (mg } 100 \mathrm{~g}^{-1} \text { peel }\right)\end{array}$ & $\begin{array}{c}\text { Carotenoids } \\
\left(\mathrm{mg} 100 \mathrm{~g}^{-1} \text { peel }\right)\end{array}$ \\
\hline 40 & $38.06 \pm 0.24 j$ & $1.85 \pm 0.00 \mathrm{k}$ \\
\hline 60 & $28.30 \pm 0.54 \mathrm{i}$ & $1.60 \pm 0.00 \mathrm{j}$ \\
\hline 80 & $23.21 \pm 0.09 \mathrm{~h}$ & $1.54 \pm 0.00 \mathrm{i}$ \\
\hline 100 & $14.67 \pm 0.04 \mathrm{~g}$ & $1.22 \pm 0.00 \mathrm{~h}$ \\
\hline 120 & $11.89 \pm 0.06 f$ & $0.97 \pm 0.00 \mathrm{~g}$ \\
\hline 140 & $9.02 \pm 0.04 \mathrm{~d}$ & $0.85 \pm 0.00 \mathrm{c}$ \\
\hline 160 & $9.49 \pm 0.02 \mathrm{~d}$ & $0.86 \pm 0.00 \mathrm{~d}$ \\
\hline 180 & $7.43 \pm 0.03 c$ & $0.93 \pm 0.00 \mathrm{e}$ \\
\hline 200 & $10.53 \pm 0.02 \mathrm{e}$ & $0.94 \pm 0.00 \mathrm{f}$ \\
\hline 220 & $7.77 \pm 0.03 c$ & $0.66 \pm 0.00 \mathrm{a}$ \\
\hline 240 & $5.84 \pm 0.04 b$ & $0.74 \pm 0.00 \mathrm{~b}$ \\
\hline 260 & $2.85 \pm 0.05 \mathrm{a}$ & $0.85 \pm 0.00 c$ \\
\hline
\end{tabular}

Data correspond to mean \pm SE; Different letters in the same graph indicate significant differences by Duncan test $(\mathrm{p} \leq 0.05)$. Values on wet basis.

$128.00 \mathrm{mg} \mathrm{GAE} \mathrm{g}^{-1}$ and $58.88 \mathrm{mg} \mathrm{GAE} \mathrm{g}^{-1}$ from 40 to $260 \mathrm{DAA}$, respectively, while a significant increase was observed in both the ether and aqueous extracts. At the end of development stage (260 DAA), the alcoholic and aqueous extracts presented the highest total phenolics content, with $58.88 \mathrm{mg} \mathrm{GAE} \mathrm{g}^{-1}$ and $57.66 \mathrm{mg} \mathrm{GAE} \mathrm{g}^{-1}$, respectively.

The highest contents of total phenolics were observed in the ether and alcoholic extracts, when compared to the values found for guava (Psidium guajava L.), which was $10.81 \mathrm{mg} \mathrm{GAE} \mathrm{g}^{-1}$ (Hassimotto et al., 2005). 
Table 3. Phenolic compounds, hydrolysable tannins, condensate tannins, and vitamin C of the different extracts of caja-manga (Spondias mombin L.) pulp along the physiological development.

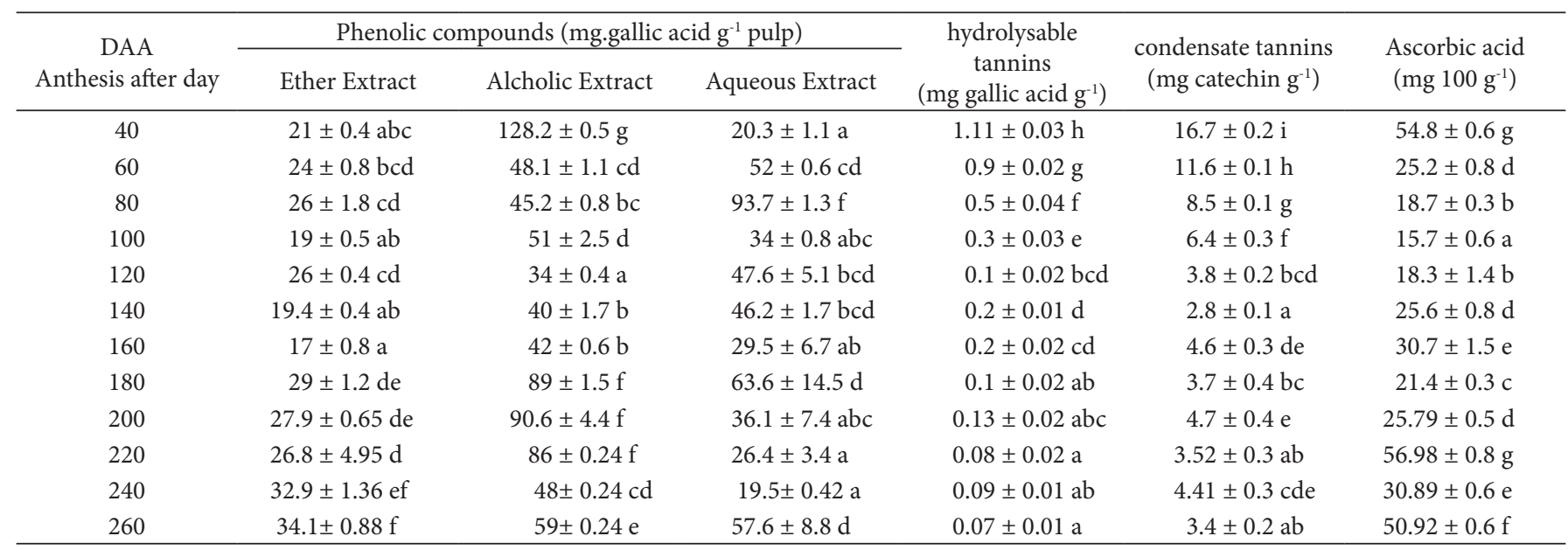

Data correspond to mean \pm SE; Different letters in the same graph, indicate significant differences by Duncan test ( $\mathrm{p} \leq 0.05)$. Values on wet basis.

Phenolic compounds have a potential antioxidant effect against oxidative processes, since they have the ability to neutralize free radicals, being associated with the prevention of chronic degenerative diseases such as cardiovascular diseases, cancer, diabetes, and premature aging (Barbosa et al, 2010; Santos et al., 2008). Tannins belong to a group of phenolic compounds of high molecular weight, and are classified into two groups - hydrolysable and condensate tannins - according to their structural differences (Degáspari et al., 2005).

The tannins content (Table 3) decreased significantly during the development stage of caja-manga, and the lower hydrolysable tannins concentration was observed at $260 \mathrm{DAA}$, when compared to the condensate tannins, with values of $0.07 \mathrm{mg}$ gallic acid g ${ }^{-1}$, and 3.4 catechin $\mathrm{mg} \mathrm{g}^{-1}$, respectively. This behavior has a positive influence over the sensory quality of the fruit, due to lower capacity of the hydrolysable tannins to complex with proteins, resulting in low astringency (Degáspari et al., 2005).

The phenolics content tend to be higher in immature fruits, as they are secondary metabolites used as plant defense mechanisms, protecting fruit at the beginning of development, allowing their maturation (Fennema, 1996).

Ascorbic acid content (Table 3) ranged along the development stage of manga caja, with higher contents at 40 DAA and 220 DAA (54.82 and $56.98 \mathrm{mg} 100 \mathrm{~g} \mathrm{~g}^{-1}$, respectively), followed by a decrease at $260 \mathrm{DAA}\left(50.92 \mathrm{mg}^{100 \mathrm{~g}^{-1}}\right)$ and $100 \mathrm{DAA}\left(15.68 \mathrm{mg}^{100 \mathrm{~g}^{-1}}\right)$.

Ibarra-Garza et al. (2015) evaluated the maturity of mango (Mangifera indica L. cv Keitt), from the El Rosario (Mexico), and found that ascorbic acid content increased by $54 \%$ during fruit development in the last ripening stage.

The ascorbic acid content found in the present study was lower than that found in Brazilian mature guava (Psidium arrack) $\left(102.00 \pm 0: 00 \mathrm{mg}^{100 \mathrm{~g}^{-1}}\right)$, cashew (Anacardium occidentale)

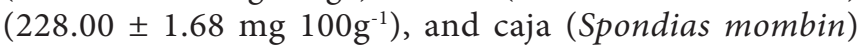
$\left(26.70 \pm 0.66 \mathrm{mg}^{100 \mathrm{~g}^{-1}}\right)$, from Colombia, and higher than the levels found in cupuaçu (Theobroma grandiflorum) $\left(7.050 .00 \pm 100 \mathrm{~g}^{-1} \mathrm{mg}\right.$ ) as reported by Contreras-Calderón et al. (2011).
According to Carocho \& Ferreira (2013), antioxidant mechanisms in biological tissues are extremely complex, and a unique determination method is not sufficient to provide reliable results. Thus, the antioxidant activity of caja-manga along the physiological development was assessed by three different assays, DPPH, ABTS and FRAP, as shown in Table 4.

In the DPPH assay, IC50 is the concentration of antioxidant required to reduce by $50 \%$ the $\mathrm{DPPH}$ radical. The lower the IC50 value, the higher the antioxidant activity of the fruit. During the physiological development, a significant increase in the antioxidant activity by DPPH assay was observed in the alcoholic extract, and a decrease in the aqueous extract, while the ether extract presented stable antioxidant activity. At the end of the development stage, at $260 \mathrm{DAA}$, ether and alcoholic extracts showed the highest antioxidant activity (IC50 $=15.13$ and 12.47 , respectively).

In the ABTS assay, an increase in the antioxidant activity was observed in the alcoholic extract during the development stage, while a decrease was observed in both ether and aqueous extracts. In the mature fruit, at $260 \mathrm{DAA}$, all extracts showed similar antioxidant activity, with $40.61,42.77$, and $55.31 \mathrm{mM} \mathrm{TE} \mathrm{g}^{-1}$, for the ether, alcoholic, and aqueous extracts, respectively.

In the FRAP assay, lower values were observed in the ether and aqueous extracts during development, with higher FRAP values in the alcoholic extract. At 260 DAA, both the alcoholic and aqueous extracts showed significantly higher ferric reducing antioxidant power, with values of 113.23 and $91.88 \mathrm{~g}^{-1} \mathrm{mM}$ ferrous sulfate, respectively.

As reported by Roesler et al. (2007), the relationship between the phenolics content and antioxidant capacity may depend on both the method chosen and hydrophobic or hydrophilic characteristics. Therefore, the FRAP method best characterized the phenolic compounds of caja-manga fruits, which exhibited antioxidant activity, predominantly iron chelating activity. 
Silva et al.

Table 4. Antioxidant activity of different caja manga (Spondias mombin L.) pulp extracts along the physiological development.

\begin{tabular}{|c|c|c|c|c|c|c|c|c|c|}
\hline \multirow{2}{*}{$\begin{array}{l}\text { Days of } \\
\text { anthesis }\end{array}$} & \multicolumn{3}{|c|}{ DPPH (IC 50) } & \multicolumn{3}{|c|}{$\mathrm{ABTS}\left(\mathrm{mM} \mathrm{TE} \mathrm{g}^{-1}\right)$} & \multicolumn{3}{|c|}{ FRAP $\left(\mathrm{mM}\right.$ ferrous sulfate $\left.\mathrm{g}^{-1}\right)$} \\
\hline & Ether Extract & $\begin{array}{c}\text { Alcholic } \\
\text { Extract }\end{array}$ & $\begin{array}{c}\text { Aqueous } \\
\text { Extract }\end{array}$ & Ether Extract & $\begin{array}{c}\text { Alcholic } \\
\text { Extract }\end{array}$ & $\begin{array}{c}\text { Aqueous } \\
\text { Extract }\end{array}$ & Ether Extract & $\begin{array}{c}\text { Alcholic } \\
\text { Extract }\end{array}$ & $\begin{array}{c}\text { Aqueous } \\
\text { Extract }\end{array}$ \\
\hline 40 & $24.6 \pm 1.02 \mathrm{ab}$ & $39.5 \pm 8.7 c$ & $22 . \pm 0.9 \mathrm{ab}$ & $111.6 \pm 11.5 \mathrm{~d}$ & $10 \pm 0.3 \mathrm{a}$ & $70 \pm 2.4 \mathrm{e}$ & $99.2 \pm 1.8 \mathrm{c}$ & $74.2 \pm 0.9 c$ & $142 \pm 1.1 \mathrm{i}$ \\
\hline 60 & $24.5 \pm 3.23 \mathrm{ab}$ & $16.5 \pm 1.4 \mathrm{ab}$ & $21.4 \pm 2.2 \mathrm{ab}$ & $70.5 \pm 7.0 \mathrm{c}$ & $139 \pm 3.6 \mathrm{f}$ & $223.8 \pm 9.6 \mathrm{f}$ & $122 \pm 0.7 \mathrm{e}$ & $292.6 \pm 2.5 \mathrm{~h}$ & $414.4 \pm 4.4 \mathrm{j}$ \\
\hline 80 & $8.4 \pm 0.9 \mathrm{a}$ & $23.4 \pm 5.4 \mathrm{~b}$ & $29.4 \pm 4.8 \mathrm{ac}$ & $65.5 \pm 11.6 \mathrm{c}$ & $60 \pm 0.7 \mathrm{e}$ & $320.2 \pm 9.3 \mathrm{~g}$ & $113 \pm 2.4 \mathrm{de}$ & $163 \pm 0.9 \mathrm{~h}$ & $540 \pm 2.2 \mathrm{k}$ \\
\hline 100 & $5.3 \pm 0.3 \mathrm{a}$ & $18 \pm 0.5 \mathrm{ab}$ & $29.1 \pm 0.8 \mathrm{ac}$ & $72.8 \pm 6.4 \mathrm{c}$ & $15 \pm 6.1 \mathrm{ab}$ & $66.2 \pm 1.4 \mathrm{de}$ & $116 \pm 4.8 \mathrm{de}$ & $94.6 \pm 0.9$ ef & $125.2 \pm 1.2 \mathrm{~h}$ \\
\hline 120 & $14.6 \pm 0.2 \mathrm{ab}$ & $16.3 \pm 1.8 \mathrm{ab}$ & $22.3 \pm 3.1 \mathrm{ab}$ & $53.6 \pm 0.7 \mathrm{bc}$ & $28.6 \pm 3.8 \mathrm{bc}$ & $35.3 \pm 1.5 \mathrm{ab}$ & $151 \pm 2.3 \mathrm{f}$ & $90 \pm 1.2 \mathrm{de}$ & $67.7 \pm 0.6 \mathrm{bc}$ \\
\hline 140 & $18.5 \pm 1.5 \mathrm{ab}$ & $14.7 \pm 1.5 \mathrm{ab}$ & $34.5 \pm 3.8 \mathrm{c}$ & $33.8 \pm 0.9 \mathrm{ab}$ & $10.5 \pm 0.7 \mathrm{a}$ & $67.6 \pm 0.9 \mathrm{de}$ & $98.4 \pm 1.9 \mathrm{c}$ & $61 \pm 3.1 \mathrm{ab}$ & $74 \pm 0.3 \mathrm{~d}$ \\
\hline 160 & $67 \pm 51.7 b$ & $16.6 \pm 1.7 \mathrm{ab}$ & $21.5 \pm 1.1 \mathrm{ab}$ & $23.5 \pm 0.7 \mathrm{a}$ & $9.7 \pm 1.1 \mathrm{a}$ & $29.2 \pm 0.7 \mathrm{a}$ & $65 \pm 3.7 \mathrm{a}$ & $53 \pm 0.8 \mathrm{a}$ & $33.3 \pm 0.6 \mathrm{a}$ \\
\hline 180 & $17.5 \pm 4.5 \mathrm{ab}$ & $14.2 \pm 0.3 \mathrm{ab}$ & $102.3 \pm 0.0 \mathrm{~d}$ & $43 \pm 9.4 \mathrm{ab}$ & $30 \pm 0.7 b c$ & $49.4 \pm 1.1 \mathrm{c}$ & $120 \pm 5.5 \mathrm{de}$ & $80 \pm 0.5 \mathrm{~cd}$ & $80.4 \pm 1.3 \mathrm{f}$ \\
\hline 200 & $11.2 \pm 0.2 \mathrm{a}$ & $16 \pm 4.2 \mathrm{ab}$ & $16 \pm 1.1 \mathrm{~b}$ & $39 \pm 1.4 \mathrm{ab}$ & $27 \pm 1.6 \mathrm{bc}$ & $63.7 \pm 1.6 \mathrm{de}$ & $111 \pm 2.8 \mathrm{~d}$ & $75 \pm 0.4 c$ & $90 \pm 0.9 \mathrm{~g}$ \\
\hline 220 & $10 \pm 0.2 \mathrm{a}$ & $10.5 \pm 0.6 \mathrm{a}$ & $24 \pm 1.1 \mathrm{ab}$ & $40.4 \pm 2.2 \mathrm{ab}$ & $30 \pm 1.9 b c$ & $43.4 \pm 1.2 \mathrm{bc}$ & $102 \pm 0.7 \mathrm{c}$ & $72 \pm 1.3 b c$ & $63 \pm 0.3 b$ \\
\hline 240 & $20.8 \pm 3.3 \mathrm{ab}$ & $13 \pm 0.6 \mathrm{ab}$ & $38.3 \pm 7.4 \mathrm{c}$ & $31 \pm 6.8 \mathrm{a}$ & $53.4 \pm 13.6 \mathrm{de}$ & $49 \pm 0.3 c$ & $78 \pm 2.2 b$ & $104 \pm 1.3 \mathrm{fg}$ & $70 \pm 0.8 \mathrm{~cd}$ \\
\hline 260 & $15.1 \pm 0.8 \mathrm{ab}$ & $12.5 \pm 1.2 \mathrm{ab}$ & $36.1 \pm 1.1 \mathrm{c}$ & $41 \pm 1.2 \mathrm{ab}$ & $43 \pm 8.4 \mathrm{~cd}$ & $55.3 \pm 0.7 \mathrm{~cd}$ & $80 \pm 0.9 \mathrm{~b}$ & $113 \pm 12.9 \mathrm{~g}$ & $92 \pm 0.2 \mathrm{~g}$ \\
\hline
\end{tabular}

Data represent mean \pm SE. Different letters in the same column indicate significant differences by Duncan test $(\mathrm{p} \leq 0.05)$. Values on a wet basis.

\section{Conclusion}

The development stage of caja-manga fruit comprised a period of 260 days, marked by a simple sigmoidal development pattern. Significant changes were observed from 200 to 220 DAA, which may be the period that fruit has reached its maturity, emphasizing phenolic, vitamin $\mathrm{C}$ and antioxidant activity.

\section{Acknowledgements}

The authors would like to thank the Brazilian sponsor $\mathrm{CNPq}$ and CAPES for financial support. Clarissa Damiani is a PQ - CNPq researcher.

\section{References}

Albuquerque, T. G., Santos, F., Sanches-Silva, A., Oliveira, M. B., Bento, A. C., \& Costa, H. S. (2016). Nutritional and phytochemical composition of Annona cherimola Mill. fruits and by-products: Potential health benefits. Food Chemistry, 193, 187-195. http://dx.doi.org/10.1016/j. foodchem.2014.06.044. PMid:26433307.

Association of Official Analytical Chemists - AOAC. (2012). Official Methods of Analysis of AOAC International (19th ed.). Gaithersburg: AOAC.

Barbosa, K. B. F., Costa, N. M. B., Alfenas, R. C. G., De Paula, S. O., Minim, V. P. R., \& Bressan, J. (2010). Estresse oxidativo: conceito, implicações e fatores modulatórios. Revista de Nutrição, 4(23), 629-643. http://dx.doi.org/10.1590/S1415-52732010000400013.

Barcia, M. T., Pertuzatti, P. B., Jacques, A. C., Godoy, H. T., \& Zambiazi, R. (2012). Bioactive compounds, antioxidant activity and percent composition of jambolão fruits (Syzygium cumini). The Natural Products Journal, 2(2), 129-138. http://dx.doi.org/10.2174/22103 15511202020129.

Berilli, S. S., Oliveira, J. G., Marinho, A. B., Lyra, G. B., Sousa, E. F., Viana, A. P., Bernardo, S., \& Pereira, M. G. (2007). Avaliação da taxa de crescimento de frutos de mamão (Carica papaya L.) em função das épocas do ano e graus-dias acumulados. Revista Brasileira de Fruticultura, 29(1), 11-14. http://dx.doi.org/10.1590/S0100-29452007000100005.

Bitter, T., \& Muir, H. M. (1962). A modified uronic acid carbazole reaction. Analytical Biochemistry, 4(4), 330-334. http://dx.doi. org/10.1016/0003-2697(62)90095-7. PMid:13971270.
Borguini, R. G. (2006). Avaliação do potencial antioxidante e de algumas características físico químicas do tomate (Lycopersicon esculentum) orgânico em comparação ao convencional (Tese de doutorado). Faculdade de Saúde Pública, Universidade de São Paulo, São Paulo.

Brune, M., Hallberg, L., \& Skanberg, A. (1991). Determination of Ironbinding phenolic groups in foods. Journal of Food Science, 56(1), 128-131. http://dx.doi.org/10.1111/j.1365-2621.1991.tb07992.x.

Carocho, M., \& Ferreira, I. C. F. R. (2013). A review on antioxidants, prooxidants and related controversy: natural and synthetic compounds, screening and analysis methodologies and future perspectives. Food and Chemical Toxicology, 51, 15-25. http://dx.doi.org/10.1016/j. fct.2012.09.021. PMid:23017782.

Carvalho, P. C. L., Ritzinger, R., Soares, W. S. Fo., \& Ledo, C. A. S. (2008). Características morfológicas, físicas e químicas de frutos de populações de umbu-cajazeira no Estado da Bahia. Revista Brasileira de Fruticultura, 30(1), 140-147. http://dx.doi.org/10.1590/ S0100-29452008000100026.

Chitarra, M. I. F., \& Chitarra, A. B. (2005). Pós-colheita de frutos e hortaliças: fisiologia e manuseio. Lavras: ESAL/FAEPE.

Contreras-Calderón, J., Calderón-Jaimes, L., Guerra-Hernández, E., \& García-Villanova, B. (2011). Antioxidant capacity, phenolic content and vitamin $\mathrm{C}$ in pulp, peel and seed from 24 exotic fruits from Colombia. Food Research International, 44(7), 2047-2053. http:// dx.doi.org/10.1016/j.foodres.2010.11.003.

Degáspari, C. H., Waszczynskyj, N., \& Prado, M. R. (2005). Atividade antimicrobiana de Schinus terebinthifolius Raddi. Ciência e Agrotecnologia, 29(3), 617-622. http://dx.doi.org/10.1590/S141370542005000300016 .

Engel, V. L., \& Poggiani, F. (1991). Estudo da concentração de clorofila nas folhas e seu espectro de absorção de luz em função do sombreamento em mudas de quatro espécies florestais nativas. Revista Brasileira de Fisiologia Vegetal, 3, 39-45.

Fennema, O. R. (1996). Food chemistry (3rd ed.). New York: Marcel Dekkan.

Franquin, S., Marcelin, O., Aurore, G., Reynes, M., \& Brillouet, J.-M. (2005). Physicochemical characterisation of the mature-green Golden apple (Spondias cythereaSonnerat). Fruits, 60(3), 203-210. http://dx.doi.org/10.1051/fruits:2005027.

Hassimotto, N. M. A., Genovese, M. I., \& Lajolo, F. M. (2005). Antioxidant activity of dietary fruits, vegetables, and commercial frozen fruit 
pulps. Journal of Agricultural and Food Chemistry, 53(8), 2928-2935. http://dx.doi.org/10.1021/jf047894h. PMid:15826041.

Higby, W. K. A. (1962). A simplified method for determination of some the carotenoid distribution in natural and carotene fortified orange juice. Journal of Food Science, 27(1), 42-49. http://dx.doi. org/10.1111/j.1365-2621.1962.tb00055.x.

Ibarra-Garza, I., Ramos-Parra, P. A., Hernández-Brenes, C., \& JacoboVelázquez, D. A. (2015). Effects of postharvest ripening on the nutraceutical and physicochemical properties of mango (Mangifera indica L. cv Keitt). Postharvest Biology and Technology, 103, 45-54. http://dx.doi.org/10.1016/j.postharvbio.2015.02.014.

Lima, M. A., \& Durigan, J. F. (2002). Reguladores vegetais na conservação pós-colheita de goiabas 'Paluma'. Revista Brasileira de Fruticultura, 24, 370-375.

Matarazzo, P. H. M., Siqueira, D. L., Salomão, L. C. C., Silva, D. F. P., \& Cecon, P. R. (2013). Desenvolvimento dos frutos de lulo (solanum quitoense lam), em Viçosa-MG. Revista Brasileira de Fruticultura, 35(1), 131-142. http://dx.doi.org/10.1590/S0100-29452013000100016.

Mattietto, R. A., Lopes, A. S., \& Menezes, H. C. (2010). Caracterização fisica e fisico-quimica dos frutos da cajazeira (Spondias mombin L.) e de suas polpas obtidas por dois tipos de extractor. Brazilian Journal of Food Technology, 13(3), 156-164. http://dx.doi.org/10.4260/ BJFT2010130300021.

McCready, P. M., \& McComb, E. A. (1952). Extraction and determination of total pectin material. Analytical Chemistry, 24(12), 1586. http:// dx.doi.org/10.1021/ac60072a033.

Miller, A., \& Schaal, B. (2005). Domestication of a mesoamerican cultivated fruit tree, Spondias purpurea. Proceeding of the National Academy of Science of the United States of America, 102(36), 1280112806. http://dx.doi.org/10.1073/pnas.0505447102.

Oms-Oliu, G., Hertog, M. L. A. T. M., Van de Poel, B., Ampofo-Asiama, J., Geeraerd, A. H., \& Nicolaï, B. M. (2011). Metabolic characterization of tomato fruit during preharvestdevelopment, ripening and postharvest shelf-live. Postharvest Biology and Technology, 62(1), 7-16. http:// dx.doi.org/10.1016/j.postharvbio.2011.04.010.

Prasanna, V., Prabha, T. N., \& Tharanathan, R. N. (2007). Fruit ripening phenomena - an overview. Critical Reviews in Food Science and Nutrition, 47(1), 1-19. http://dx.doi.org/10.1080/10408390600976841. PMid:17364693.

Price, M. L., Van Scoyoc, S., \& Butler, L. G. (1978). A critical evaluation of the vanillin reaction as an assay for tannin in sorghum grain. Journal of Agricultural and Food Chemistry, 26(5), 1214-1218. http:// dx.doi.org/10.1021/jf60219a031.
Roesler, R., Malta, L. G., Carrasco, L. C., Holanda, R. B., Sousa, C. A. S., \& Pastore, G. M. (2007). Atividade antioxidante de frutas do Cerrado/ Antioxidant activity of cerrado fruits. Food Science and Technology, 27(1), 53-60. http://dx.doi.org/10.1590/S0101-20612007000100010.

Rufino, M. S. M., Alves, R. E., Brito, E. S., Morais, S. M., Sampaio, C. G., Pérez-Jiménez, J., \& Saura-Calixto, F. D. (2006). Metodologia científica: determinação da atividade antioxidante total em frutas pelo método de redução do ferro (FRAP) (Embrapa Agroindústria Tropical, Comunicado Técnico, No. 125, 4 p.). Fortaleza: Embrapa Agoindústria Tropical.

Rufino, M. S. M., Alves, R. E., Brito, E. S., Morais, S. M., Sampaio, C. G., Pérez-Jiménez, J., \& Saura-Calixto, F. D. (2007). Metodologia científica: determinação da atividade antioxidante total em frutas pela captura do radical livre ABTS•+ (Embrapa Agroindústria Tropical, Comunicado Técnico, No. 128, 4 p.). Fortaleza: Embrapa Agoindústria Tropical.

Santos, G. M., Maia, G. A., Sousa, P. H. M., Costa, J. M. C. C., Figueiredo, R. W., \& Prado, G. M. (2008). Correlação entre atividade antioxidante e compostos bioativos de polpas comerciais de açaí (Euterpe oleracea Mart). Archivos Latinoamericanos de Nutricion, 58(2), 187-192. PMid:18833997.

Silva, P. M. C., Neves, L. C., Bastos, V. J., Lima, C. G. B., Araújo, K. G. M., \& Roberto, S. R. (2016). Harvesting period of Murici (Byrsonima crassifolia Kunth) fruit in relation to physical and chemical parameters evaluated during fruit development. Scientia Horticulturae, 200, 66-72. http://dx.doi.org/10.1016/j.scienta.2015.12.041.

Strohecker, R., \& Henning, H. M. (1967). Analisis de vitaminas: metodos comprobados (428 p.). Madrid: Paz Montalvo.

Taiz, L., \& Zeiger, E. (2004). Fisiologia vegetal (pp. 449-484). Porto Alegre: Artmed.

Tiburski, J. H., Rosenthal, A., Deliza, R., Godoy, R. L. O., \& Pacheco, S. (2011). Nutritional properties of yellow mombin (Spondias mombin L.) pulp. Food Research International, 44(7), 2326-2331. http://dx.doi. org/10.1016/j.foodres.2011.03.037.

Watada, A. E., Herner, R. C., Kader, A. A., Romani, R. J., \& Staby, G. L. (1984). Terminology for the description of developmental stages of horticultural crops. HortScience, 19, 20-21.

Waterhouse, A. L. (2002). Polyphenolics: determination of total phenolics. In R. E. Wrolstad. Current protocols in food analytical chemistry (pp. 111-118). New York: John Wiley \& Sons.

Wongmetha, O., Ke, L. S., \& Liang, Y. S. (2015). The changes in physical, bio-chemical, physiological characteristics and enzyme activities of mango cv. Jinhwang during fruit growth and development. NJAS - Wageningen Journal of Life Sciences, 72-73, 7-12. https://doi. org/10.1016/j.njas.2014.10.001. 